\title{
KARYA ROH KUDUS DALAM MENINGKATKAN KUALITAS SUMBER DAYA MANUSIA (SDM)
}

\author{
Gidion \\ (gideon_JOSILA@yahoo.com)
}

\begin{abstract}
Abstraksi
Kualitas Sumber Daya Manusia (SDM) merupakan kebutuhan vital dalam menjawab tuntutan kebutuhan akan layanan Gereja yang baik, layanan lembaga pendidikan yang baik, dan efektifitas organisasi/lembaga. Alkitab mengkisahkan latar belakang para Rasul atau murid Yesus yang berawal dari kelompok tidak terpelajar dan berprofesi sebagai nelayan. Tampaknya sebuah ironi yang mengejutkan ketika Yesus dalam misiNya yang besar dengan waktu yang "tak banyak", menetapkan murid-murid yang tidak memiliki "SDM" mempuni sebagai tim sekerjaNya. Namun sejarah pelayanan para Rasul memperlihatkan peran Roh Kudus dalam meningkatkan kualitas sumber daya manusia (SDM) para Rasul.Penelitian ini bertujuan melihat karya Roh Kudus dalam meningkatkan kualitas sumber daya manusia.
\end{abstract}

\section{A. PENDAHULUAN}

Manusia merupakan sentral dari pembangunan suatu Bangsa dan Gereja, sehingga keberhasilan suatu Bangsa atau Gereja sangat bergantung pada sumber daya manusianya. Human Devolopment Report dari UNDP dalam beberapa tahun terakhir menunjukkan bahwa kualitas SDM Indonesia tergolong relative rendah, bahkan terburuk diantara Negara-negara ASEAN. Pada tahun 2003 Indonesia menduduki peringkat 122 dari 175 negara dunia, dalam peringkat kualitas SDM. Dan pada tahun 2007 menjadi peringkat 107 dari 177 negara dunia dalam peringkat kualitas SDM. ${ }^{1}$ Kualitas Sumber Daya Manusia (SDM) merupakan kebutuhan vital dalam menjawab tuntutan kebutuhan akan layanan Gereja yang baik, layanan lembaga pendidikan yang baik, dan efektifitas organisasi/lembaga. Setiap Lembaga/organisasi tentunya membutuhkan tenaga kerja yang memiliki sumber daya manusia yang berkompeten guna menunjang keberhasilan lembaga melaksanakan tugas tanggungjawabnya.

Dewasa ini masyarakat semakin kritis dan dinamis, sehingga dibutuhkan lahirnya pemimpinpemimpin yang mampu membuat perubahan yang berarti bagi gereja dan masyarakat. Perubahan positif merupakan peluang yang diciptakan oleh sumber daya manusia pemimpin yang kompoten. Oleh sebab itu harus diakui, bahwa keberhasilan memimpin ditentukan oleh faktor kualitas pemimpin. . 'Sumber daya manusia' lebih akan terbukti unggul pada saat pemimpin mengahadapi kondisi yang sulit, dimana SDM-lah yang akan membebaskan pemiliknya dari kesulitan yang dihadapi. ${ }^{3}$ Hal ini pun diakui oleh seorang pakar kepemimpinan dalam pertumbuhan gereja, yaitu John C. Maxwell, dimana ia menulisnya dalam sebuah buku yang mengulas tentang "Kepemimpinan Pada Abad XXI " ${ }^{4}$ Jadi dapatlah disimpulkan bahwa pemimpin yang berkualitas dapat menciptakan kepemimpinan yang berkualitas.

Alkitab mengkisahkan latar belakang para Rasul atau murid Yesus yang berawal dari kelompok tidak terpelajar dan berprofesi sebagai nelayan. Tampaknya sebuah ironi yang mengejutkan

\footnotetext{
${ }^{1}$ Priyono Tjiptoherijanto dan Laila Nagib, Pengembangan Sumber Daya Manusia; di antara peluang dan tantangan (Jakarta: LIPI, 2008), 2.

${ }^{2}$ Panitia Seminari Pertumbuhan Gereja "Theologia Pertumbuhan Gereja" Makalah Seminar Pertumbuhan Gereja (Jakarta: Panitia SPG, 1989), 36.

${ }^{3}$ Yakob Tomatala, Pemimpin Yang Handal, (Malang: Gandum Mas, 1997), 60.

${ }^{4}$ C. Peter Wagner, Gempa Gereja, (Jakarta: Nafiri Gabriel, 2000), 10-12.
} 
ketika Yesus dalam misiNya yang besar dengan waktu yang tak banyak, menetapkan murid-murid yang tidak memiliki "SDM" mempuni sebagai tim sekerjaNya. Namun sejarah pelayanan para Rasul memperlihatkan kualitas pelayanan yang luar biasa dari para Rasul; Petrus sang Nelayan menjadi pembicara yang membawa 3000 orang yang sebelumnya menolak Yesus bertobat menerima Yesus sebagai Juruselamat. Petrus dan Yohanes membuat imam-imam, kepala pengawal bait Allah, orangorang Saduki terheran-heran dengan keberanian dan kecerdasan mereka, padahal Petrus dan Yohanes adalah orang biasa dan bukanlah terpelajar (Kis. 4:13). Konteks Kisah Para Rasul pasal menjelaskan bahwa hal sensasional ini terjadi dikarenakan karya Roh Kudus dalam pribadi para Rasul.

Sejarah doktrin Roh Kudus menunjukkan bahwa sejak abad ke-2 gereja menuai kontroversi sengit mengenai topik ini. Gereja memiliki penafsiran yang beragam, dan sulit sependapat dalam menentukan sikap dan ajarannya. Problematika ini juga yang menyebabkan beberapa teolog sistematika enggan membahas topik ini. Menurut Erickson sikap golongan Pentakosta yang lebih menonjolkan doktrin ini, hingga mengklaim dirinya lebih baik dari golongan lain, menyebabkan orang non Pentakosta enggan membicarakan hal ini, karena takut dipandang orang Pentakosta. ${ }^{5}$ Sejarah Gereja merekam perkembangan Gereja yang fluktuatif, dimana Gereja pernah mengalamai masa kegelapan dan masa kebangkitan. Beberapa ahli berkata bahwa masa kegelapan dikarenakan Gereja telah mendistorsi pemahaman akan karya Roh Kudus dalam Gereja, dan akibatnya Gereja masuk pada masa kegelapan. Dan sejarah Gereja kembali merekam bahwa pada masa kegelapan Gereja terjadi pergeseran esensi-esensi kepercayaan Kristen, yang menyebabkan gereja kehilangan fungsinya.

Roh Kudus merupakan inisiator yang memimpin Gereja atau orang percaya dalam peningkatan yang progresif. Roh Kudus-lah yang akan membimbing orang percaya mengerti seluruh Kebenaran Allah dan yang membimbing ke dalam progresifitas. Oleh karya Roh Kudus sajalah pikiran manusia dapat dicelikkan hingga dapat memahami kebenaran-Kebenaran yang Yesus ajarkan. ${ }^{6}$ Peran Roh Kudus dalam sejarah Gereja di masa lalu membuktikan bahwa peningkatan kualitas orang percaya bergantung terhadap peranan Roh Kudus. Tentu ada beragam penafsiran dan cara pandang yang dimiliki mengenai topik karya Roh Kudus atas orang percaya, namun yang menjadi hal mutlak adalah bahwa Alkitab merupakan dasar dan rule dalam membangun teologi dan doktrin.

\section{B. METODOLOGY}

Berdasarkan permasalahan dan tujuan penelitian yang telah dipaparkan sebelumnya, maka ancangan yang digunakan untuk penelitian ini adalah ancangan post positivis. Penelitian post positivis adalah penelitian yang berorientasi pada paradigma interpretatif dan konstruktif. Post positivisme memandang realitas sosial sebagai suatu yang kompleks, holistik, dinamin, dan penuh makna. ${ }^{7}$ Sedangkan rancangan penelitian yang digunakan adalah rancangan penelitian kualitatif. Penelitian kualitatif digunakan jika masalah penelitian belum jelas, jika peneliti ingin mengetahui makna yang tersembunyi dari objek yang diteliti, jika peneliti ingin memahami interaksi sosial, jika peneliti ingin mengembangkan teori, dan jika peneliti meneliti sejarah perkembangan. ${ }^{8}$ Peneliti bertujuan menemukan peran atau karya Roh Kudus dalam peningkatan sumber daya manusia.

\section{SUMBER DAYA MANUSIA (SDM)}

${ }^{5}$ Millard J. Erickson, Teologi Kristen, 27.

${ }^{6}$ "Roh Kudus..., Dialah yang akan mengajarkan segala sesuatu kepadamu dan akan mengingatkan kamu akan semua yang telah Kukatakan kepadamu" (Yoh. 14:26). Alkitab terjemahan LAI, 2002.

${ }^{7}$ M. Djunadi dan Fauzan Almanshur, Metode Penelitian Kualitatif (Yogyakarta: Ar-Ruzz Media, 2012), 28.

${ }^{8}$ Juliansyah Noor, Metodologi Penelitian (Jakarta: Kencana Prenada Media Group, 2011), 34. 
Dalam pengertian umum sumber daya didefinisikan sebagai sesuatu yang dipandang memiliki nilai ekonomi. Oleh karena alam memiliki nilai ekonomi seperti objek wisata, tambang, itu sebabnya semua ini disebut sumber daya alam. Namun beberapa negara yang tidak memiliki sumber daya alam yang baik, mengubah haluan dan berinvestasi pada pengembangan sumber daya manusia. ${ }^{9}$ Rees dalam bukunya menjelaskan bahwa sesuatu dapat dikatakan sumber daya bila ada pengetahuan atau ketrampilan untuk memanfaatkannya, dan bilamana terdapat permintaan terhadap sumber daya tersebut. Jadi sumber daya amat terkait dengan kegunaan (usefulness), baik pada masa kini dan masa yang akan datang.

Perusahaan atau lembaga organisasi apapun membutuhkan manusia-manusia dengan kualitas terbaik untuk menunjang berjalannya perusahaan dan lembaga dengan baik, dan mempercepat tercapainya keberhasilan perusahaan atau lembaga. Pada masa kini manusia tidak hanya dipandang sebagai sumber daya atau sesuatu yang memiliki nilai ekonomi semata, melainkan memandang manusia sebagai asset atau modal sebuah perusahaan atau lembaga. Sumber daya manusia tidak lagi dilihat dari perspektif beban atau cost, tetapi sebagai asset yang bernilai dan dapat dilipatgandakan. ${ }^{10}$

Secara mendasar aspek sumber daya manusia terletak pada kualitas atau kuantitas pengetahuan dan pengalaman. ${ }^{11}$ Oleh sebab itu peningkatan kualiatas sumber daya manusia harus bertumpu pada pengembangan pendidikan dan latihan yang sebaik-baiknya. Spencer dalam bukunya merinci aspek-aspek Sumber Daya Manusia diantaranya adalah kompetensi pengetahuan, ketrampilan, sikap, dan prilaku. Dalam dunia kerja kompetensi sumber daya manusia yang diperlukan adalah Hard Skill (pengetahuan dan ketrampilan), Soft Skill (intuisi dan kepekaan), Social Skill (ketrampilan membangun hubungan), Mental Skill (ketahanan mental).

\section{KARYA ROH KUDUS ATAS ORANG PERCAYA}

Karya Roh Kudus atas orang percaya tidak dapat dipisahkan dari karya besar penyelamatan manusia. Dan menurut pemahaman Paulus masalah keselamatan berpusat pada bagaimana masalah dosa dapat diselesaiakan. ${ }^{12}$ Menurut Paulus dosa adalah pemberontakan terhadap Allah, sikap tidak takluk kepada ketentuan Allah (Rom. 8:7), dan ketidaktaatan terhadap Allah (Rom. 11:32). Alasan dosa inilah yang menjadi dasar penyelamatan Allah terhadap manusia, dan di dalam penyelamatan inilah Roh Kudus berkarya atas manusia. Harun Hadiwiyono dalam bukunya yang berjudul "Inilah Sahadatku" mengatakan bahwa Roh Kudus datang kepada orang percaya, untuk menerapkan hasil karya penyelamatan yang telah diperoleh Yesus melalui kematian, kebangkitan, dan kenaikan-Nya ke Sorga ${ }^{13}$ Demikian juga J. Verkuyl dalam bukunya mengatakan, bahwa Roh Kudus bertugas untuk melanjutkan, menyelesaikan, dan menyempurnakan pekerjaan Allah Bapa dan Anak. ${ }^{14}$ Jadi melalui Roh Kudus karya penyelamatan Allah dapat terwujud nyatakan dalam pribadi manusia, sebab oleh

${ }^{9}$ Priyono Tjiptoherijanto dan Laila Nagib, Pengembangan Sumber Daya Manusia; di antara peluang dan tantangan (Jakarta: LIPI, 2008), 9.

${ }^{10}$ Charles R. Greer, Strategy Anda Human Resourches; A General managerial perspective (New Jersy: Prentice Holy, 1995.

${ }^{11}$ S. Effendi dan Ohta. S, Ultisols of "Lowland Dipterocarp Forest” In East Kalimantan, 1992.

${ }^{12}$ J. Manuain, Doktrin Dan Konteks (Malang: Institut Injili Indonesia Batu-Malang, 1990), 25 .

${ }^{13}$ Menjadikan hasil karya penyelamatan yang Yesus kerjakan itu, benar-benar menjadi milik orang-orang yang percaya. Harun Hadiwiyono, Inilah Sahadatku (Jakarta: BPK Gunung Mulia,2006), 128.

${ }^{14}$ Dalam Yohanes 16:13,14 Yesus berfirman: "tetapi apabila Ia datang, yaitu Roh Kebenaran, Ia akan memimpin kamu ke dalam seluruh kebenaran" J. Verkuyl, Aku Percaya; Uraian Tentang Injil Dan Seruan Untuk Percaya, 168. 
karya Roh Kudus manusia dapat mengaku bahwa Yesus adalah Tuhan (1Kor. 12:3), dan melalui karya Roh Kudus pula manusia memiliki karakter Kristus.

Rasul Paulus menjelaskan bahwa Roh Kudus diberikan dalam hati orang percaya sebagai jaminan (down payment) untuk menerima karya ilahi yang telah disediakan Allah bagi orang percaya (2Kor. 1:20-22). Sebab itu Nazarius Rumpak dalam tulisannya mendefinisikan bahwa karya Roh Kudus merupakan bentuk kasih karunia atau anugerah Allah atas orang percaya. ${ }^{15}$ Jadi karya Roh Kudus oleh Nazarius merupakan tindakan aktif pribadi Roh Kudus dalam menyatakan karya ilahi atau kasih karunia Allah pada manusia.

\section{Karya Roh Kudus Dalam Perjanjian Lama}

Berdasarkan konteks Perjanjian Lama, orang Israel memahami bahwa Roh Kudus yang berperan mengurapi pemimpin-pemimpin mereka. Pada zaman hakim-hakim disebutkan bahwa Otniel, Gideon, Yefta dan Simson adalah orang yang hidupnya dikuasai oleh Roh, yang menjadikan mereka pemimpin kharismatis (Hak. 3:10; 6:34; 11:29; 13:25). Roh Kudus juga pernah memenuhi Saul ketika menjadi raja, sehingga ia memiliki kemampuan dalam mengemban tugas menjadi raja (1Sam. 11:6), namun karena ketidak taatannya Roh Kudus kemudian undur dari pada Saul (1Sam. 16:14). Ketika Samuel mengurapi Daud dikatakan, "sejak hari itu dan seterusnya berkuasalah Roh Tuhan atas Daud" (1Sam. 16:13), dan Roh juga berbicara melalui perantaraan Daud (2Sam. 23:2). Dalam mazmurnya Daud menunjukkan, bahwa Roh Kuduslah yang memberikan tuntunan untuk hidup sesuai dengan kehendak Bapa, sehingga manusia dapat mencapai kemenangan (Maz. 143:10).

Pada masa monarki Israel, Roh memegang peranan sentral melalui jabatan nabi. Yehezkiel mengatakan bahwa ia menjadi nabi karena Roh telah memasukinya (Yeh. 2:2). Mikha adalah seorang yang dipenuhi Roh Tuhan (Mik. 3:8), Zakhariah mengatakan bahwa Firman yang disampaikan para nabi adalah Firman dari Roh Allah (Zak. 7:12). Jadi jelas bahwa dalam konteks perjanjian lama antara Firman dan Roh tidak dapat dipisahkan. Seorang nabi adalah penyambung lidah Allah yang penuh dengan Roh (Hos. 9:7), dan hanya menyampaikan apa yang Roh Kudus ingin sampaikan, bukan hasil rekayasa para nabi (Yes. 42:1).

Dari penjelasan diatas tampak jelas bahwa Roh Kudus berperan secara aktif sejak awal masa penciptaan dan dalam sejarah panjang umat Allah di PL, Roh Kudus yang memampukan para hakim, raja, dan nabi untuk memimpin umat kepada tujuan penyelamatan Allah. Allah memilih hakim dan raja untuk memimpin umatNya kepada kebenaran-kebenaran Allah, agar umat hidup menurut nilainilai yang berasal dari Allah dan bukan atas keinginan manusia sendiri (Hak. 17:6; 21:25). Bahkan setelah kejahatan itu semakin besar, Allah memilih nabi-nabi yang sangat luar biasa untuk berbicara kepada para raja dan umat Allah dengan tegas dan lantang.

Roh Kudus sebagai pribadi Allah tidak dapat mentolerir segala bentuk dosa yang dilakukan manusia, karena hakekat ke-AllahanNya yang adalah kudus (Kej. 6:1-8). Sejarah Perjanjian Lama menunjukkan bahwa Roh Kudus yang mengurapi para nabi untuk berbicara kepada para umat, agar umat kembali pada nilai-nilai moral yang Allah tentukan. Tidak hanya berbicara melalui para nabi, namun Roh Kudus juga mendidik serta membimbing umat Allah untuk hidup dalam ketaatan kepada Allah (Neh. 9:20a; Yehz. 36:27). Harun Hadiwiyono dalam tulisannya menyatakan bahwa "Roh Kudus yang dinamis itu mengandung di dalamnya sifat-sifat yang etis; ancaman hukuman pada anak yang murtad (Yes. 30:1)."16

2. Karya Roh Kudus Dalam Perjanjian Baru

\footnotetext{
${ }^{15}$ Nazarius Rumpak, Masa Roh Kudus Dan Kasih Karunia (Jakarta: BPK Gunung mulia, 1988), 9.

${ }^{16}$ Harun Hadiwiyono, Iman Kristen, 114.
} 
Konsep Perjanjian Lama mengenai peranan Roh Kudus, kembali dikonfirmasi dalam konteks Perjanjian Baru. Penulis-penulis Perjanjian Baru memahami bahwa seluruh perkataan nabinabi perjanjian lama merupakan perkataan yang berasal dari Roh Kudus (Kis. 1:16; 4:25; 28:25; dan Rom. 7:6). Jadi sesuai dengan kepercayaan terhadap salah satu pokok pengakuan Iman Nicea, bahwa Roh Kudus telah berfirman dengan perantaraan para Nabi dalam masa perjanjian lama, ${ }^{17}$ maka Roh Kudus juga berperan dalam kehidupan masyarakat perjanjian baru melalui para Rasul, untuk membimbing orang-orang percaya kepada kebenaran Allah yang sejati.

Roh Kudus terus berkarya melewati masa para Nabi dan para Rasul, dan pada masa kini Roh Kudus berperan secara intensif dalam hidup orang percaya melalui gereja sebagai tools-Nya. John R.W Stoot dalam tulisannya menyatakan bahwa Alkitab Perjanjian Lama dan Perjanjian Baru memberikan bukti bahwa Roh Kudus terus berinteraksi pada manusia. Roh Kudus sebagai pribadi Allah yang kekal tetap ada dan terus bekerja sebelum dan sesudah hari pentakosta. ${ }^{18}$ Mempelajari karya Roh Kudus sama pentingnya dengan mempelajari karya keselamatan yang dikerjakan Yesus, sebab Roh Kudus hadir dan berkarya menindaklanjuti pekerjaan Yesus pasca kebangkitan. Harun Hadiwiyono menegaskan bahwa "demikian juga Roh Kudus dapat disamakan dengan Kristus, Anak Allah, dilihat dari segi ini, bahwa Roh itu adalah Kristus yang hadir berbuat untuk menjadikan orangorang milikNya menikmati hasil karya penyelamatan-Nya." 19

Sebelum kenaikan-Nya Yesus menjanjikan seorang penolong lain $\pi \alpha \rho a ́ k \lambda \eta \tau o \varsigma$ (dipanggil untuk berjalan di samping), yang kemudian akan berada disamping para murid seperti sebelumnya Yesus yang berada disamping para murid. "Penolong lain" yang adalah Allah Roh Kudus bekerja melanjutkan karya penyelamatan pasca kebangkitan Yesus, dimana hanya melalui Roh Kudus saja dapat diketahui kebenaran yang sesungguhnya (Yoh. 14:26; 16:7-15). Roh Kudus yang hadir ditengahtengah gereja untuk memimpin gereja dalam menyelesaikan polemik-polemik yang dihadapi oleh gereja. Fakta yang tidak dapat dipungkiri bahwa kedua puluh tujuh kitab Perjanjian Baru ditulis bukan pada masa Yesus berada di bumi, melainkan setelah peristiwa di atas loteng Yerusalem.

\section{a. Karya Roh Kudus Mengajar Orang Percaya}

Sebelum Yesus naik ke sorga, ia berjanji akan mengutus Roh Kudus kepada para murid dan orang percaya, sebagai penolong yang memipin mereka ke dalam seluruh kebenaran-kebenaran Allah. Roh Kudus sebagai penolong atau parakletos diutus untuk mendampingi, menerangi budi orang percaya, sehingga dapat mengerti apa yang telah diajarkan oleh Yesus (Yoh. 14:26). Berdasarkan kamus besar bahasa Indonesia kata mengajar didefinisikan memberi petunjuk supaya diketahui. Dan Hendry C. Thiessen dalam bukunya menegaskan kembali, bahwa peranan Roh Kudus dalam mengajar adalah menuntun orang percaya kepada seluruh kebenaran yang telah difirmankan atau diajarkan oleh Yesus (Yoh. 14:26; 16:13). ${ }^{20}$

Erickson dalam tulisannya mendefinisikan bahwa peranan Roh Kudus dalam mengajar orang percaya adalah membantu orang-orang percaya masa kini untuk memahami dengan benar berita yang tertulis dalam Kitab Suci. ${ }^{21}$ Setiap orang percaya yang telah mengalami peristiwa lahir baru di dalam

\footnotetext{
${ }^{17}$ Alkitab berasal dari Allah, berpusat pada Kristus dan diilhamkan oleh Roh Kudus. Jadi
} Alkitab atau Firman kebernaran adalah kesaksian Bapa tentang Anak yang disampaikan melalui Roh Kudus. John R.W Stoot, Alkitab Buku Untuk Masa Kini (Jakarta: Persekutuan Pembaca Alkitab, 1990), 30.

${ }^{18}$ John R.W Stoot, Kedaulatan Karya Kristus (Jakarta: Yayasan Komunikasi Bina Kasih/OFM, 1991), 93.

${ }^{19}$ Harun Hadiwiyono, Iman Kristen, 131.

${ }^{20}$ Hendry C. Thiessen, Teologi Sistematika, 389.

${ }^{21}$ Millard J. Erickson, Teologi Kristen, 53. 
hidupnya ada Roh Kudus, dan Roh Kudus yang telah mengilhami penulisan Alkitab akan menerangi pikiran orang-orang percaya tersebut untuk mengerti segala hal tentang Allah; yaitu segala hal yang baik dan berkenan menurut kehendak Allah melalui isi Alkitab. E.P Ginting dalam bukunya mengatakan; "jika para Nabi atau Rasul sebagai penulis-penulis Kitab berbicara atas nama Allah dengan kekuatan Roh Kudus (2Pet. 1:2), maka Roh Kuduslah yang memberikan pengertian tentang apa yang mereka tulis. ${ }^{22} \mathrm{Hal}$ ini dapat dimungkinkan sebab Roh Kudus mampu mendeskripsikan secara lengkap dan benar apa yang menjadi kehendak Allah (1Kor. 2:10-11).

Peranan Roh Kudus mengajar orang percaya dinyatakan melalui pemberian hikmat kepada orang percaya, untuk dapat memahami sesuatu yang tidak mungkin dipahami melalui akal pikiran biasa (1 Kor. 2:13). Mengenai ayat ini Millad J. Erickson menjelaskan:"Karunia-karunia Roh Kudus diberikan dalam kata-kata yang diajarkan ( $\delta \iota \delta \alpha \kappa \tau o ́ s)$ oleh Roh dan bukan oleh hikmat manusia (1Kor. 2:13). Dari semua pertimbangan ini, tampaklah bahwa Paulus tidak sedang mengatakan bahwa orangorang yang tidak rohani itu mengerti tetapi tidak menerima. Tetapi sebaliknya, orang-orang yang tidak rohani itu tidak menerima, setidak-tidaknya sebagian karena mereka tidak memahami." ${ }^{23}$

Peranan Roh Kudus menjadi hal vital dalam memahami segala sesuatu yang Allah ingin nyatakan kepada orang percaya. Sebab hikmat Allah itu di luar jangkauan mata, telinga, dan pikiran manusia. Ia tidak tunduk kepada penelitian ilmiah, juga terhadap imajinasi. Hikmat Allah sama sekali di luar batas dan daya ukur akal kita yang sempit dan terbatas, kecuali Allah sendiri menyatakannya. Namun apa yang tidak pernah dilihat oleh mata, yang tidak pernah timbul di dalam hati manusia: semua itu disediakan Allah bagi yang mengasihi Dia (1Korintus 2:9), yaitu tuntunan-Nya melalui Roh Kudus untuk mengajari orang percaya. Betapa pentingnya pencerahan yang diberikan oleh Roh Kudus untuk mengerti Firman Allah, sampai-sampai penulis Surat Yohanes menggunakan kalimat “... tidak perlu kamu diajar oleh orang lain" (1Yoh. 2:27).

Roh Kudus mengajar dengan cara memperbaharui akal budi orang percaya, untuk memahami kebenaran Firman Allah. Roh Kudus adalah Guru yang akan mengarahkan akal budi orang percaya, sebab itu akal atau nalar orang percaya tidak diabaikan. Namun E.P Ginting menegaskan bahwa akal budi digunakan bukan untuk mengkritik Firman, melainkan dipergunakan untuk menggumuli, berusaha memahami, mengahayati, dan merelevansikan Firman dalam kehidupan seharihari. ${ }^{24}$ Selain melalui pembaharuan akal budi, Roh Kudus juga mengajar orang percaya melalui gereja yang merupakan tubuh Kristus. Roh Kudus mengajar orang percaya secara tak langsung dengan perantaraan saudara seiman dan jemaat setempat (Ef. 3:18-19).

Peran Roh Kudus mengajar orang percaya tidak hanya dibatasi pada area agama saja, melainkan pada seluruh area hidup manusia. G. C Van Niftrik dalam bukunya menjelaskan karya Roh Kudus dalam mengajar orang percaya melalui Alkitab, untuk menjelaskan bahwa Kristus merupakan Tuan yang mengatur dan bertanggungjawab di segala lapangan hidup. ${ }^{25}$ Lapangan hidup orang percaya hanya akan menjadi lebih baik, bila orang percaya tetap berdoa (Maz. 119:19) supaya Roh Kudus dengan perantaraan Alkitab menerangkan apa yang harus dilakukan orang percaya, yang sesuai dengan kehendak Allah.

Roh Kudus merupakan Agen yang mengajarkan wahyu Allah pada orang percaya. John R.W Stoot dalam bukunya yang berjudul "Basic Chritian Leadrship" mengatakan: "Paul give us a comprehensive statement of the ministry of the Holy Spirit as the agent of the divine revelation. He

\footnotetext{
${ }^{22}$ E.P Ginting, Khotbah dan Pengkhotbah (Jakarta: BPK. Gunung Mulia, ), 40.

${ }^{23}$ Millard J. Erickson, Teologi Kristen, 323.

${ }^{24}$ E.P Ginting, Khotbah Dan Pengkhotbah, 41.

${ }^{25}$ G.C Van Niftrik \& B.J Boland, Dogmatika Masa Kini (Jakarta: BPK Gunung Mulia, 2008),
} 401. 
presented to us in four stages as "searching", "revealing", "inspiring", and "enlightening". 26 (Paulus memberikan kita pernyataan komprehensif dari pelayanan Roh Kudus sebagai agen dari wahyu Ilahi. Dia menyajikan dalam empata tahap kepada kita diantaranya: "menyelidiki", "menyatakan", "mengilhami", dan" menerangi").

1) Roh Kudus Menyelidiki

Tahap pertama yang Roh Kudus kerjakan dalam rangka mengajar orang percaya adalah menyelidiki pikiran dan kehendak Allah (1Kor. 2:10-11). Ini merupakan pekerjaan yang dilakukan pribadi Roh Kudus, sebab Roh kudus adalah pribadi yang memiliki akal pikiran yang melaluinya dapat menyelidiki pikiran dan kehendak-kehendak Allah. Penggunaan istilah "menyelidiki" sepadan dengan istilah yang sering digunakan untuk menjelaskan pekerjaan orang Yahudi yang berusaha menyelidiki Kitab-kitab Suci. Istilah ini juga menggambarkan ketelitian para petugas beacukai.

Paulus mungkin meminjam istilah 'dalam' dari perbendaharaan kata bidat Gnostik, untuk menjelaskan keberadaan Allah yang tak terukur kedalaman-Nya dalam (1Kor. 2:10). Dengan istilah ini Paulus secara terus terang menyatakan bahwa Roh Kudus menyelidiki kedalaman-kedalaman Allah. John Stoot mengatakan "at all events, the holy spirit is depicted as restlessly inquisitive researcher, even-deep sea diver seeking to fathom the deepest depths of the being of God". ${ }^{27}$ (dalam semua peristiwa, Roh Kudus digambarkan sebagai penyelidik yang berusaha mengetahui, digambarkan juga sebagai penyelam yang mencoba memahami kedalaman terdalam dari kedalaman diri Allah).

Kemampuan Roh kudus dalam menyelidiki pikiran Allah, juga digambarkan dalam bentuk pengertian manusia tentang dirinya sendiri. "Siapa gerangan di antara manusia yang tahu, apa yang terdapat di dalam diri manusia selain roh manusia itu sendiri?" (1Kor. 2:11). Ungkapan 'Apa yang terdapat' menunjuk kepada hal-hal khusus yang hanya diketahui simanusia itu sendiri. Manusia sekalipun tidak mungkin dapat menyelami sepenuhnya keberadaan diri seorang manusia lainnya, selain roh simanusia itu sendiri. Kemampuan diri dalam memahami diri sendiri inilah yang digunakan Paulus untuk menggambarkan kapasitas kemampuan Roh Kudus dalam meyelidiki pikiran Allah. Itu sebabnya dalam 1Korintus 2:11b dikatakan bahwa tidak ada orang yang tahu, apa yang terdapat di dalam diri Allah selain Roh Allah (Roh Kudus) itu sendiri.

\section{2) Roh Kudus Menyatakan}

Langkah selanjutnya setelah Roh Kudus menyelidiki apa yang ada dalam pikiran Allah adalah menyatakan apa yang diselidiki-Nya. Dalam 1Korintus 2:10 dikatakan bahwa "kepada kita (para rasul) Allah telah menyatakannya oleh Roh." Kemudian dalam 1Korintus 2:12 Paulus menguraikannya: "Kita (para rasul) tidak menerima roh dunia, tetapi roh yang berasal dari Allah (yaitu Roh yang menyelidik dan yang mengetahui), supaya kita tahu, apa yang dikaruniakan Allah kepada kita." Jadi Roh Kuduslah yang memampukan mereka untuk mengerti keselamatan yang adalah anugerah Allah.

Karya Roh Kudus menyatakan ajaran Injil kasih karunia, Dia menyatakan apa yang telah Allah buat untuk orang-orang berdosa yang sebenarnya tidak pantas menerima kasih karunia. Paulus menyatakan bahwa Allah telah mengutus Anak-Nya untuk mati di salib bagi dosa-dosa

${ }^{26}$ John R.W Stoot, Basic Christian Leadershi: Biblical Models Of Church, Gospel And Ministry (Downers Gorve: InterVarsity Press, 2002), 61.

${ }^{27}$ John R.W Stoot, Basic Christian Leadership, 62-63. 
manusia dan bangkit kembali, dan melalui iman dan baptisan pertobatan maka manusia turut mati bersama Dia dan bangkit kembali dengan Dia, mengalami suatu kehidupan baru di dalam Dia. Injil ajaib seperti inilah yang Paulus ungkapkan kepada orang percaya dalam surat- suratnya. Pertanyaannya adalah bagaimana Paulus dapat mengetahui semua ini? Bagaimana Paulus dapat membuat uraian selengkap ini tentang konsep keselamatan? Menurut John Stoot Jawabannya adalah "he had received the Holy Spirit to interpret his experience to him. Thus the searching Spirit became the revealing Spirit, making God and his work of salvation known to the biblical authors". ${ }^{28}$ (Paulus telah menerima Roh Kudus untuk menafsirkan pengalamannya. Jadi Roh Kudus yang menyelidiki menjadi Roh Kudus yang mengungkapkan segala hal tentang Allah dan karya keselamatan-Nya untuk diketahui oleh penulis-penulis Alkitab).

3) Roh Kudus Mengilhamkan

Setelah Roh Kudus menyatakan apa yang dikehendaki Allah untuk dinyatakan, tahap selanjutnya dari karya Roh Kudus mengajar adalah mengilhamkan. Dalam 1Korintus 2:13b dikatakan bahwa para Rasul berkata-kata tentang karunia-karunia Allah dengan perkataan yang bukan diajarkan oleh hikmat manusia, melainkan oleh Roh. Dalam ayat sebelumnya menjelaskan ajaran apa yang diterima oleh Paulus dari Roh Kudus, dan pada ayat 13 menjelaskan ajaran apa yang disampaikan oleh Paulus. Roh yang menyelidiki pikiran Allah telah menyatakan ajaran tentang Allah dan karya keselamatan ke dalam pikiran para Rasul, selanjutnya mengilhami para Rasul dalam meneruskan penyampaian ajaran Firman Allah itu kepada orang-orang lain. Jadi sama seperti Roh tidak menyimpan hasil-hasil penyelidikan-Nya untuk diri-Nya sendiri, demikian pula para rasul tidak menyimpan penyataan dari-Nya itu untuk diri mereka sendiri.

Dalam menjelaskan content ajaran Firman yang telah dinyatakan oleh Roh Kudus dalam pikiran para Rasul, Paulus mengunakan istilah "berkata-kata" dan "perkataan" yang diajarkan oleh Roh. Mengenai istilah ini John Stoot menjelaskan bahwa: Verbal inspiration means that what the Holy Spirit spoke through the biblical authors (understood according to its literary genre, its plain, natural meaning, the intention of the human authors and each context) is true and without error. ${ }^{29}$ (pengilhaman secara lisan artinya bahwa apa yang Roh Kudus bicarakan melalui para penulis Alkitab [pemahaman menurut jenis sastra yang digunakan, kepolosan, alamiahnya, makna dasar, maksud penulis dan tiap konteksnya) adalah benar dan tanpa kesalahan).

\section{4) Roh Kudus Menerangi}

Allah Roh Kudus yang telah mengilhami para Rasul dalam menyampaikan ajaran kepada orang percaya, dan juga bagi umat Tuhan pada masa kini melalui Alkitab yang tanpa salah, selanjutnya mengajar orang-orang percaya dengan cara menerangi pikirannya. Roh Kudus yang telah mengilhami perkataan para Rasul untuk menyapaikan ajaran-Nya, selanjutnya dengan giat berkarya di dalam diri mereka yang membaca tulisan para Rasul tersebut. Jadi Roh Kudus bekerja di dalam keduanya, yaitu mengilhamkan firman-Nya kepada para Rasul dan menerangi para pendengar Firman itu. Secara tidak langsung hal ini disinggung dalam 1Korintus 2:13a, dimana Roh Kudus menafsirkan kebenaran-kebenaran rohani kepada mereka yang memiliki Roh (orang yang telah mengalami kelahiran baru).

Peranan Roh Kudus dalam mengajar menjadi sangat penting, karena menentukan pertumbuhan kerohanian orang percaya. Namun Roh Kudus hanya akan mendiami pribadi yang telah mengalami lahir baru, untuk selanjutnya mengajar orang percaya memahami rahasia Ilhai

\footnotetext{
${ }^{28}$ John R.W Stoot, Basic Christian Leadership, 64.

${ }^{29}$ Ibid., 67.
} 
melalui Firman Allah. Sebab itu manusia tidak rohani atau yang belum diperbaharui, tidak juga menerima perkara-perkara dari Roh Kudus karena hal itu merupakan kebodohan bagi mereka (1Kor. 2:14).

\section{b. Karya Roh Kudus Memperbaharui Orang Percaya}

Karya Roh Kudus dalam memperbaharui orang percaya sama maknanya dengan dengan momentum kelahiran baru, dimana manusia yang sebelumnya telah dilahirkan dari daging dilahirkan kembali dari Roh. Ada banyak istilah yang digunakan untuk merujuk gagasan kelahiran baru, diantaranya; dilahirkan kembali, dilahirkan dari atas, diperanakkan kembali, diperbaharui, ciptaan baru, manusia baru, dan dilahirkan. Sekalipun istilah yang digunakan cukup beragam, namun esensi kelahiran baru jelas terungkap dari istilah-istilah yang digunakan Alkitab tersebut.

Dalam kitab Perjanjian Lama karya Roh Kudus dalam memperbaharui orang percaya diungkapkan dalam Yehezkiel 36:26-27, dijelaskan bahwa Allah memperbaharui orang percaya dengan memberikan hati yang baru, roh yang baru di dalam batin orang percaya, dan menjauhkan (NIV: remove) hati yang keras. Dan dalam ayat 27 dijelaskan bahwa Roh Kudus akan diberikan dalam batin orang percaya, sehingga orang percaya dapat memiliki hati yang baru, yaitu hati yang taat pada segala ketetapan/ketentuan yang Allah berikan.

Pada dasarnya ungkapan "dilahirkan kembali”, bukan pertama kali muncul dalam percakapan antara Yesus dengan Nikodemus. Istilah ini sudah dikenal di kalangan orang Yahudi, bila ada orang non-Yahudi menjadi Yahudi dan diterima ke dalam ke-Yahudian dengan doa, persembahan korban dan baptisan, maka orang tersebut dianggap sebagai dilahirkan kembali. Para rabi mengatakan: "Orang asing yang memeluk agama Yahudi adalah seperti seorang anak yang baru lahir." ${ }^{30}$ Perubahan itu begitu radikal, sehingga dosa-dosa yang pernah dilakukannya dienyahkan, sebab sekarang ia telah menjadi orang yang baru. Jadi jelas bagi orang Yahudi, orang Yunani, dan orang purbakala, ide kelahiran kembali bukanlah sesuatu yang baru.

Menilik dalam kitab Perjanjian Baru, ada beragam istilah ditemukan mengenai kelahiran baru, namun mengandung gagasan yang tidak jauh berbeda. Dalam percakan antara Yesus dan Nikodemus, Yesus memberikan pernyataan; “...jika seorang tidak dilahirkan kembali, ia tidak dapat melihat Kerajaan Allah", kata dilahirkan kembali menggunakan kata $\gamma \epsilon \nu \nu \eta \theta \eta$ (aorist pasif;begat/telah dilahirkan) $\ddot{\alpha} \nu \omega \theta \epsilon \nu$ (from above, dari atas). Jadi dapat diterjemahkan; "jika seorang belum dilahirkan

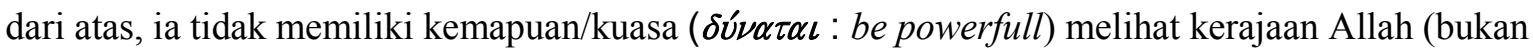
surga $^{31}$ ). Penjelasan mengenai 'dilahirkan kembali dari atas' dijelaskan dalam ayat 3 , yaitu lahir dari air dan roh. Dalam tafsirannya Barclay mengatakan bahwa air adalah symbol pembersihan, dan roh adalah symbol kuasa. Jadi orang yang dilahirkan kembali dibersihkan dari segala dosanya, dan diberi

${ }^{30}$ Bukan hanya orang Yahudi yang mengetahui hal kelahiran kembali, dunia kuno termasuk orang-orang Yunani pun telah mengenal dengan baik segala hal tentang lahir kembali dan kelahiran baru. Mereka yang hidup waktu itu sangat merindukannya dan mencarinya ke mana-mana. Salah satu upacara agama rahasia yang sangat terkenal ialah yang disebut taurobolium. Calon yang ikut dalam upacara itu dimasukkan ke dalam lubang di tanah yang ditutup dengan kisi-kisi. Di atas kisi-kisi itu, tepat di mulut lubang tersebut seekor lembu disembelih. Darah lembu tersebut mengucur ke dalam lubang, dan si calon mengangkat kepalanya serta membasuh dirinya dengan darah tersebut. Ketika ia keluar dari lubang itu ia disebut renatus in aeternum, dilahirkan kembali di dalam kekekalan. William Barclay, Pemahaman Alkitab Setiap Hari Injil Yohanes (Jakarta: BPK. Gunung Mulia, 2008), 214.

${ }^{31}$ Kerajaan Allah basilei,an tou/ qeou artinya kedaulatan Allah pada masa kini. George Eldon Ladd, Teologi Perjanjian Baru 2, 80-87. 
kuasa yang ilahi dalam dirinya untuk sanggup melakukan segala ketetapan Allah yang sebelumnya tidak sanggup dikerjakan manusia oleh karena keterbatasannya sebagai manusia. ${ }^{32}$

Makna kelahiran baru sering juga disebut sebagai "dijadikan oleh firman kebenaran" atau "dilahirkan oleh Allah" (1Pet. 1:3,23). Pada teks ini kelahiran baru menggunakan kata á $\nu \alpha \gamma \epsilon \nu \nu \eta ́ \sigma \alpha \varsigma$ (aorist aktif: born again, lahir kembali). Berdasarkan konteks dijelaskan bahwa kelahiran kembali disebabkan oleh penebusan melalui darah Yesus Kristus di kayu salib dan oleh firman Allah. Sebab itu siapapun yang mengalami kelahiran kembali ini disebut sebagai ciptaan baru, sebab mereka yang ada dalam Kristus adalah ciptaan baru (2Kor. 5:17). Etimologi lain dari gagasan kelahiran baru terdapat dalam ayat yang berkata; “...Dia telah menyelamatkan kita, bukan karena perbuatan baik yang telah kita lakukan, tetapi karena rahmat-Nya (Yesus) oleh permandian kelahiran kembali ( $\pi \alpha \lambda \iota \gamma \gamma \epsilon \nu \in \sigma i \alpha \varsigma$. recreation) dan oleh pembaharuan yang dikerjakan oleh Roh Kudus (Tit. 3:5). Jadi anugerah penyelamatan Yesus nyatakan melalui karya Roh Kudus dalam menciptakan atau melahirkan kembali manusia dan memperbaharuinya.

Berdasarkan tensisnya, kata kerja yang digunakan untuk menyampaikan gagasan kelahiran baru selalu dalam bentuk tensis aorist. Penggunaan tensis aorist adalah untuk menjelaskan suatu kegiatan yang telah selesai. Erickson dalam tulisannya menjelaskan bahwa peristiwa kelahiran baru terjadi secara seketika, sekali dan sempurna. ${ }^{33}$ Jadi kelahiran baru bukanlah sebuah proses, melainkan suatu peristiwa yang sekali saja terjadi dalam pribadi orang percaya.

Chris Marantika mendefiniskan kelahiran baru sebagai tindakan dari setiap orang yang bertobat dari dosa-dosanya dan beriman kepada Tuhan Yesus sebagai Juruselamat pribadinya yang berarti telah lahir baru, diangkat oleh Allah menjadi anggota keluarga-Nya dan berhak mewarisi Kerajaan Allah bersama orang-orang beriman lainnya." ${ }^{, 34}$ Erickson dalam tulisannya mendefinisikan karya Roh Kudus memperbaharui orang percaya sebagai tindakan Allah mengubah orang percaya, dimana Allah menganugerahkan vitalitas rohani serta arah hidup yang baru pada saat mereka menerima Kristus. ${ }^{35}$ Donald Guthrie dalam penjelasannya mengenai lahir baru, menjelaskan perubahan arah hidup itu dengan konsep perubahan kodrat. Baginya lahir baru merupakan pertukaran kodrat lama seseorang menjadi kodrat yang baru, penerimaan suatu asal-usul yang baru, perjalanan masuk kepada hubungan yang baru dengan Allah, melalui Yesus Kristus. ${ }^{36}$ William Barclay mendifinisikannya sebagai keadaan lahir kedua secara rohani, ketika manusia mengasihi Yesus dan membuka dirinya untuk Yesus masuk. ${ }^{37}$

Dari penjelasan di atas dapat dirumuskan bahwa makna kelahiran baru pada dasarnya berbicara mengenai karya ilahi dalam mengubah prinsip berpikir dan arah hidup manusia, melalui penerangan pada pikiran manusia untuk mempercayai Yesus sebagai Juruselamat, yang olehnya manusia mengalami pembaharuan hidup. Dan moment kelahiran baru itu terjadi ketika se-orang percaya diterangi pikirannya oleh Roh Kudus, sehingga sadar dan mempercayai bahwa Yesus adalah Tuhan dan Juruselamat. Jadi dapatlah disimpulkan bahwa karya Roh Kudus dalam memperbaharui orang percaya adalah menjadikan manusia percaya bahwa Yesus adalah Tuhan dan Juruselamat dan memberi vitalitas rohani untuk hidup sesuai dengan ketetapan Allah, atau disebut juga dengan perubahan arah hidup. ${ }^{38}$

\footnotetext{
${ }^{32}$ William Barclay, Pemahaman Alkitab Setiap Hari Injil Yohanes, 220.

${ }^{33}$ Millard J. Erickson, Teologi Kristen, 157.

${ }^{34}$ Chris Marantika, Doktrin Keselamatan dan Kehidupan Rohani (Yogyakarta: Iman Press, 2002), 126-127.

${ }^{35}$ Millard J. Erickson, Teologi Kristen, 153.

${ }^{36}$ Donal Guthrie, Teologi Perjanjian Baru 2, 228.

${ }^{37}$ William Barclay, Pemahaman Alkitab Setiap Hari Injil Yohanes, 221.

${ }^{38}$ Millard J. Erickson, Teologi Kristen, 153.
} 
1. Memungkinkan Manusia Ber-iman Kepada Yesus

Karya Roh Kudus yang pertama dalam memperbaharui orang percaya adalah menerangi pikiran manusia untuk dapat memahami arti Injil yang sesungguhnya. George Eldon Ladd mengatakan bahwa karya Roh Kudus pertama dalam pribadi orang percaya adalah memungkinkan manusia untuk memahami karya penebusan ilahi. Salib yang merupakan kebodohan bagi orang Yunani dan batu sandungan bagi Yahudi, namun oleh karya Roh Kudus menerangi pikiran manusia, hal itu dimengerti manusia sebagai kasih karunia dan kebijaksanaan Allah. ${ }^{39}$

Dalam Yohanes 16:8-9 Yesus berkata bahwa Roh Kudus akan datang untuk menginsafkan dunia akan dosa, karena mereka tidak percaya bahwa Yesus adalah Tuhan. Namun setelah Roh Kudus tercurah dalam peristiwa Pentakosta, dijelaskan bahwa orang banyak yang sebelumnya ikut menyalibkan Yesus bertobat dan percaya bahwa Yesus adalah Tuhan, melalui Injil yang diberitakan Petrus (Kis. 2:23). Menurut Eldon Ladd ada makna yang tersembunyi di dalam peristiwa kematian Kristus yang tidak dapat dilihat oleh mata lahiriah, dan hanya dapat dipahami oleh pencerahan adi kodrati. ${ }^{40}$ Jadi hanya oleh penerangan Roh Kudus sajalah manusia dapat memahami makna salib yang sesungguhnya, sehingga manusia mengakui bahwa Yesus yang mati disalib itu adalah Tuhan (1Kor. $12: 3)$.

Kelahiran kembali yang merupakan peristiwa kelahiran secara rohani dari perspektif Allah, ditandai dengan iman yang percaya bahwa Yesus adalah Tuhan (2Kor. 5:17; Tit. 3:5-6). Dalam kitab Perjanjian Lama kata percaya menggunakan kata Qal (dalam bentuk kata kerja), kata ini sering diterjemahkan "kesetiaan", dalam bentuk niphal artinya menjadi "kokoh, teguh, mantap". Bila mendapatkan kata depan $\Xi$ mengandung arti "bersandar pada sesuatu dengan penuh keyakinan". Menurut Erickson makna kata ini lebih tepat diterjemahkan "hati yang mampu bertahan pada sabda dan janji Ilahi". ${ }^{41}$

Dalam kitab Perjanjian Baru kata percaya menggunakan kata kerja $\pi \iota \sigma \tau \epsilon u ́ \omega$, oleh Friberg Lexicon kata ini diterjemahkan intellectual evaluation believe (percaya yang berdasarkan evaluasi intelektual). Menurut Erickson kata ini menunjukkan tindakan meyakini bahwa sesuatu itu adalah benar adanya. ${ }^{42}$ Berdasarkan teks Yunani, kata percaya lebih condong didasarkan pada pembuktian secara akal atau nalariah. Namun Donal Guthrie dalam bukunya mengatakan bahwa penggunaan kata iman dalam kitab perjanjian Baru lebih mengarah kepada pribadi Yesus sendiri, dan mencakup unsur mempercayakan diri kepada-Nya (Yoh.4:50; 8:30; 12:11; 14:1). ${ }^{43}$ Kedua makna di atas membangun makna iman, yaitu sebagai tindakan mempercayakan diri secara penuh pada pribadi Yesus, yang didasarkan pada persetujuan akal. Jadi dapat dipahami bahwa iman dibentuk oleh pengertian yang benar, sebab iman selaras dengan akal. Jadi karya Roh Kudus pertama dalam memperbaharui orang percaya adalah memampukan akal manusia untuk memahami bahwa Yesus sungguh-sungguh adalah Allah (Yoh. 15:26). Akal manusia yang telah diterangi oleh Roh Kudus inilah yang menjadikan manusia kokoh, mantap, dan bersadar penuh dalam keyakinan mempercayai Yesus sebagai Tuhan dan Juruselamat.

\footnotetext{
${ }^{39}$ George E. Ladd, A Theology Of The New Testament (Grand Rapids: Eerdmans, 1974), 490491 dikutip oleh Erickson, 136.

${ }^{40}$ George E. Ladd, $A$ Theology Of The New, 490-491.

${ }^{41}$ Millard J. Erickson, Teologi Kristen, 148.

${ }^{42}$ Millard J. Erickson, Teologi Kristen, 149.

${ }^{43}$ Donal Guthrie, Teologi Perjanjian Baru 2, 223.
} 


\section{Perubahan Arah Hidup}

Kelahiran baru yang dikerjakan Roh Kudus menyebabkan perubahan arah hidup yang baru pula pada orang percaya. Elisa B. Surbakti dalam bukunya menyebut hal ini sebagai perubahan kodrat lama kepada kodrat yang baru, penerimaan suatu jenis asal usul yang baru, suatu perjalanan masuk kepada hubungan yang baru kepada Allah. ${ }^{44}$ Kehidupan dalam kematian rohani menyebabkan kecenderungan pada tindakan pemberontakan terhadap Allah, sedangkan kehidupan dalam Kristus menyebabkan kecenderungan untuk hidup benar di hadapan Allah. Itu sebabnya Agustinus menentang ajaran Pelagianus, dan mengatakan bahwa hanya oleh anugerah yang berasal dari pihak Allah saja manusia dapat untuk tidak melakukan dosa dan berbuat kebajikan. ${ }^{45}$

Eldon Ladd dalam tulisannya menjelaskan bahwa karya Roh Kudus dalam memperbaharui menjadi sangat penting, karena manusia telah mengalami kematian secara rohani, sehingga diperlukan kelahiran baru yang secara rohani pula. ${ }^{46}$ Menurut Erickson manusia yang belum mengalami pembaharuan atau kelahiran kembali tidak dapat menyadari dan menanggapi ransangan rohani, Alkitab menggambarkan mereka sebagai orang buta, tuli, dan mati. ${ }^{47}$ Menurut John Wesley ketika manusia mengalami kematian secara rohani, manusia tidak sanggup lagi hidup dalam kekudusan, kebenaran, dan kasih. Oleh sebab itu manusia harus dilahirkan kembali secara rohani, yaitu melalui iman kepada Yesus. ${ }^{48}$

Rasul Yohanes menandaskan bahwa setiap orang yang lahir dari Allah tidak akan terusmenerus berbuat dosa (1Yoh. 3:9; 5:18). William Barclay dalam tafsirannya mengatakan bahwa orang percaya yang mengalami kelahiran baru diberi kuasa yang ilahi dalam dirinya, untuk sanggup melakukan segala ketetapan Allah yang sebelumnya tidak sanggup dikerjakan manusia oleh karena keterbatasannya sebagai manusia. ${ }^{49}$ Dalam Yehezkiel 36:27 dijelaskan bahwa Roh Kudus diberikan dalam batin orang percaya, sehingga dapat memiliki hati yang taat pada segala ketetapan Allah. Jadi Roh Kudus yang berperan menginsafkan pikiran manusia sehingga menyadari apa yang berkenan dan tidak berkenan dihadapan Allah (Yoh. 16:8-11), dan memberi manusia kuasa untuk memperbaharui kehidupannya (Yoh. 3:5-8). Perubahan mendasar dalam arah kehidupan seseorang dari kecenderungan untuk berbuat dosa kepada keinginan untuk hidup benar disebut kelahiran baru. ${ }^{50}$

Choan-seng Song dalam bukunya menjelaskan bahwa melalui Roh Kudus saja manusia dapat memiliki karakter dari ciptaan baru. Roh Kudus memampukan orang percaya mengalahkan halangan-halangan yang telah dibuat oleh dosa. ${ }^{51}$ Barclay dalam tafsirannya menjelaskan bahwa kelahiran baru berbicara mengenai mutu kehidupan yang dibangun oleh penghormatan dan ketaatan yang sempurna kepada Allah. Mutu kehidupan ini hanya mungkin dimiliki orang percaya melalui anugerah yang berasal dari Allah. Jadi Roh Kudus yang memungkinkan perubahan kecenderungan 2008), 96.

${ }^{44}$ Elisa B. Surbakti, Benarkah Yesus Juruselamat Universal? (Jakarta: BPK Gunung Mulia, 103-104.

${ }^{45}$ Agustinus, Against Two Letters Of The Pelagianus, 24 dikutip oleh Millard J. Erickson,

${ }^{46}$ Geoge Eldon Ladd, Theology Of The New Testament, 290.

${ }^{47}$ Millard J. Erickson, Teologi Kristen, 153.

${ }^{48}$ Richard Maruli Daulay, Mengenal Gereja Methodist (Jakarta: BPK Gunung Mulioa, 2004), 25.

${ }^{49}$ William Barclay, Pemahaman Alkitab Setiap Hari Injil Yohanes, 220.

${ }^{50}$ Millard J. Erickson, Teologi Kristen, 96.

${ }^{51}$ Choan-seng Song, Sebutkanlah Nama-nama Kami; teologi cerita dari perspektif Asia (Jakarta: BPK Gunung Mulia, 1999), 148. 
keinginan dalam pribadi orang percaya, dan memampukan orang percaya untuk dapat menghormati dan mentaati Allah sebagaimana seharusnya. ${ }^{52}$ Rasul Paulus menghubungkan kelahiran baru dengan kemampuan yang diterima sesorang dari Roh Kudus, untuk mematikan perbuatan-perbuatan daging (Rom. 8:9-13). Menurut Bruce istilah kelahiran baru dalam teologi tidak boleh dipisahkan dari tindakan perubahan moral sepanjang hidup untuk lebih mendekati citra Kristus."

Paulus menjelaskan kepada jemaat di Galatia tentang hidup oleh Roh dengan ditandai tidak hidup menurut keinginan daging. Perbuatan daging yang dimaksudkan adalah percabulan, kecemaran, hawa nafsu, penyembahan berhala, sihir, perseteruan, perselisihan, iri hati, amarah, kepentingan diri sendiri, percideraan, roh pemecah, kedengkian, kemabukan, pesta pora dan sebagainya (Gal. 5:11-21). Roh Kudus menolong orang percaya melepaskan diri dari ikatan perbuatan daging dan memimpinnya untuk hidup dalam kekudusan. Melalui Roh Kudus orang percaya memiliki gaya hidup manusia yang dibaharui, dan Roh Kudus melakukan pembaharuan tersebut secara utuh dalam totalitas manusia (Rom.12:2; 2Kor. 3:18). Roh Kudus bukan hanya bekerja memperbaharui bagian batin manusia saja, melainkan Roh Kudus menampakkan kuasaNya dan realitasNya dalam pekerjaanNya yang nampak mengubah karakter atau prilaku moral manusia.

\section{E. KESIMPULAN}

Konteks kitab Kisah Para Rasul menjelaskan betapa amat besarnya pengaruh dari para Rasul dihadapan tua-tua Yahudi dan orang-orang terkemuka masa itu, ini merupakan hal sensasional karena latar belakang para Rasul yang bukanlah orang-orang terpelajar, namun Kitab Kisah Para Rasul menyaksikan bahwa karya Roh Kudus dalam pribadi dan pelayanan para Rasul sebagai kunci terciptanya pengaruh besar yang dilakukan oleh rasul-rasul sederhana ini. Peran Roh Kudus dalam sejarah Gereja di masa lalu membuktikan bahwa peningkatan kualitas orang percaya bergantung terhadap peranan Roh Kudus.

Aspek peningkatan sumber daya manusia dapat dilihat dari Hard Skill (pengetahuan dan ketrampilan), Soft Skill (intuisi dan kepekaan), Social Skill (ketrampilan membangun hubungan), Mental Skill (ketahanan mental). Rasul Paulus menjelaskan bahwa Roh Kudus diberikan dalam hati orang percaya sebagai jaminan (down payment) untuk menerima karya ilahi yang telah disediakan Allah bagi orang percaya (2Kor. 1:20-22), yang menjadikan manusia memiliki kualitas manusia yang lebih baik. Roh Kudus menyanggupkan akal manusia yang sederhana, memahami hal-hal yang supranatural. Karya Roh Kudus merupakan tindakan aktif pribadi Roh Kudus dalam menyatakan karya ilahi atau kasih karunia Allah pada manusia.

Peran Roh Kudus dalam meningkatkan kualitas sumber daya manusia adalah mengajar dan membaharui/meningkatkan kualitas sumber daya manusia. Dalam mengajar orang percaya, Roh Kudus menyatakan, mengilhamkan, menerangi setiap orang percaya untuk memiliki pengenalan akan Allah dan kebenaran-kebenaran ilahi. John Navone dan Thomas Cooper dalam pembahasannya mengenai pengembangan sumber daya manusia dibidang pengetahuan mengutip pandangan Thomas Aquinas yang menegaskan bahwa kebahagiaan akhir akal budi adalah memiliki pengenalan akan Allah. ${ }^{54}$ Dalam membaharui/meningkatkan kualitas sumber daya manusia, Roh Kudus menyanggupkan pikiran manusia memahami hal-hal ilahi dan mengalami peningkatan kualitas hidup.

\footnotetext{
${ }^{52}$ William Barclay, Pemahaman Alkitab Setiap Hari Injil Yohanes, 219-221.

${ }^{53}$ Bruce Milne, Mengenali Kebenaran Panduan Iman Kristen (Jakarta: BPK Gunung Mulia),

${ }^{54}$ John Navone, Toward a Theology of Beauty (Yogyakarta: Kanisius, 2007), 52. 286. 


\section{DAFTAR PUSTAKA}

Calvin, Yohanes. Institutio: Pengajaran Agama Kristen. Jakarta: BPK Gunung Mulia, 2008.

Cho, Paul Yonggi. Roh Kudus, Adimitra Saya. Jakarta: Pekabaran Injil Immanuel, 2000.

Darmaputera, Eka. Anak Tangga Menuju Hidup Berkemenangan. Jakarta:BPK Gunung Mulia, 2008.

Drescher, John. Melakukan Buah Roh. Jakarta: BPK Gunung Mulia, 2008.

Enns, Paul. The Moody Handbook Of Theology Jilid 1. Malang: SAAT, 2006.

Fletcher, Verne H. Lihatlah Sang Manusia. Jakarta: BPK Gunung Mulia, 2007.

Graham, Billy. Roh Kudus. Bandung: Lembaga Literatur Baptis, 1996.

Greer, Charles R. Strategy Anda Human Resourches; A General managerial perspective.New Jersy: Prentice Holy, 1995.

Horton, Stanley M. Oknum Roh Kudus. Malang: Gandum Mas, 2001.

Ingram, Chip. Road To Spiritual Maturity. Dallas: Veritas Dallas Theological Seminary, 2010.

Jong, Paul C. Satu-Satunya Cara Yang Pasti Untuk Anda Menerima Roh Kudus. Korea Selatan: The New Life Mission, 2001.

Manuain, J. Doktrin Dan Konteks. Malang: Institut Injili Indonesia Batu-Malang, 1990.

Milne, Bruce. Mengenali Kebenaran Panduan Iman Kristen, Jakarta: BPK Gunung Mulia.

Noumen, Henri J.M. Menggapai Kematangan Hidup rohani. Yogyakarta: Kanisius, 1985.

Oentoro, Jimmy. Live Full lives. Jakarta: Harvest Publication House, 2008. . Menjadi Gereja Yang Berpengaruh. Jakarta: Gramedia Pustaka Utama, 2010.

Packer, J.I. Kebutuhan Gereja Saat Ini Kerajaan Allah dan Kuasa-Nya. Malang: Gandum Mas, 2001.

Purnomo, Aloys Budi. Roh Kudus Jiwa Gereja Yang Hidup. Yogyakarta: Kanisius, 1998.

Rumpak, Nazarius. Masa Roh Kudus Dan Kasih Karunia. Jakarta: BPK Gunung mulia, 1988.

Stott, J.R.W. Kedaulatan Dan Karya Kristus. Jakarta: Komunikasi Bina Kasih/OMF, 1991.

Tjiptoherijanto, Priyono dan Laila Nagib. Pengembangan Sumber Daya Manusia; di antara peluang dan tantangan. Jakarta: LIPI, 2008.

White, Jerry. Kejujuran Moral Dan Hati Nurani. Jakarta: BPK Gunung Mulia, 2004. 